\title{
Water Pollution by Heavy Metals in The Western Lagoon and its Effect on Timsah Lake and Consequently on Suez Canal
}

\author{
Hoda Abd El-Azim ${ }^{1}$, Aisha A.Belal ${ }^{1}$, Enas Taha Abd El-Salam ${ }^{2}$, Fekry A. Mourad ${ }^{1}$ and Safaa Y. Abo Elwafa ${ }^{2}$ \\ ${ }^{1}$ National Institute of Oceanography and Fisheries, Gulfs of Suez and Aqaba brach, Attaka, Suez, Egypt \\ ${ }^{2}$ Chemistry Department, Suez Canal University, Ismailia, Egypt
}

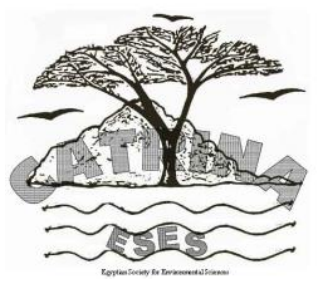

\begin{abstract}
This work is devoted to assessing the sources and pollution levels of nine heavy metals $(\mathrm{Fe}, \mathrm{Mn}, \mathrm{Cu}, \mathrm{Ni}$, $\mathrm{Zn}, \mathrm{Cr}, \mathrm{Co}, \mathrm{Pb}$, and $\mathrm{Cd}$ ) in Timsah Lake water with respect to its effect on surrounding waters. Heavy metals were measured by applying solvent extraction to 12 water samples collected, from inshore and offshore stations of Timsah Lake including the western lagoon and Suez Canal. The environmental parameter for the study area was also, measured. From the results, it appeared that heavy metals in water follow the order: $\mathrm{Fe}>\mathrm{Zn}>\mathrm{Pb}>\mathrm{Cu}>\mathrm{Mn}>\mathrm{Co}>\mathrm{Cr}>\mathrm{Cd}>\mathrm{Ni}$ and their concentrations are significantly high in the north and western edges of the lake more than the middle. Stations 5, 7, 9, and 12 (at the bridge near the western lagoon) had the highest levels of most studied metals, these stations characterized by a huge amount of agriculture, the domestic, and industrial pollutant. While $\mathrm{Fe}$ and $\mathrm{Cu}$ had their highest levels $(15.34$ and $145 \mu \mathrm{g} / \mathrm{L})$ at station 6 in fronts of Abo Halos drain and Villas and cabins including Tourism activities. The lowest levels of studied metals were in stations that lie away from the sources of pollution and its effects.
\end{abstract}

Keywords: Heavy metals, Suez Canal, Timsah Lake, water pollution, western lagoon.

\section{INTRODUCTION}

Timsah Lake is one of the most important lakes in Egypt. The lake plays an important role in most of the activities in Ismailia City, such as tourism and navigation and considered a source of the important local fishery (Kaiser et al., 2009). It receives high salinity water from the Suez Canal mainly from the South (ElSerehy and Sleigh, 1992). It also receives fresh water from the Ismailia Canal, El-Forsan drain from the North and from drains such as Al-Mahasama drain and Abu Jamous drain via western Lagoon (El-Sherbiny et al., 2011). The increasing human activities on the banks of the lake affected negatively, especially along the southern shores. The dredging operations of the Suez Canal as well contributed to the deterioration of the lake's ecosystem and led to the demolition of fisheries (Abdel Sabour et al., 1998). The rapid growth of population activities in recent years around Timsah Lake such as shipbuilding and maintenance, municipal wastewater damping off and agricultural drainage loading in the lake have greatly increased the eutrophication and pollution status of the lake (Kaiser et al., 2009). All of the previously mentioned conditions threatened the health of the lake; interfere with its recreational purpose, lake richness and diversity of indigenous fish, phytoplankton, zooplankton, plants and animal population (Kamel, 2013 and Mehanna et a.l, 2016).

At least, there are three major sources responsible for the heavy metal contamination in Timsah Lake (area of interest) namely, agricultural drainage, industrial drainage and municipal (sewage) effluent. In the last three decades, the aquatic ecosystem of Timsah Lake recorded hazardous levels of a pollutant of various forms, heavy metals concentrations in the water, sediments and marine fauna (Abd El-Azim, 2002; Gabr and Gab-Alla, 2008). Heavy metals considered the most hazardous contaminant in the environment because of their persistence in water, sediments, and bio-magnifications in tissues of the living organisms (Dembitsky, 2003). Overpopulation, industrialization, rapid urbanization, overuse of pesticides, detergent and agricultural chemicals, liquid and solid waste products and discharge of municipal wastes resulted in heavy metal pollution of natural water resources (Baruah et al., 2011).

Mehanna et al., (2016) mentioned that the fish production of Timsah Lake declined in the recent years to its half. This is not only for overfishing and illegal mesh sizes but also for severe pollution and the great fluctuation in salinity and temperature. Western Lagoon has not received any attention, although it is considered the entrance to Timsah Lake from the western side and the main cause of pollution in the Lake. Moreover, the specific water quality of the lake affects the essential role of the Suez Canal as a major waterway on the migration of the organisms (Lessipsian and Antilessipsian) migration (Kamel, 2013). According to the high loads of pollutants which reached the western lagoon from several sources, and mobilized at Lake Timsah and thus to the Suez Canal, which would negatively impact on them, so it became necessary to study the environment of this region and variables which have undergone, including the marine environment of water, for visualizing and the extent of its impact on the surrounding environment of Lake Timsah and try to find the appropriate solutions to the problems of pollution.

The main objectives of this study are: to determine the concentration of heavy metals in the water, of the western lagoon of Timsah Lake to assess a baseline data on the current pollution status of the lagoon and its effect on Timsah Lake and consequently on Suez Canal.In this respect, the present study demonstrates qualitative investigations of nine heavy metals, $\mathrm{Fe}, \mathrm{Mn}$, $\mathrm{Cu}, \mathrm{Ni}, \mathrm{Zn}, \mathrm{Cr}, \mathrm{Co}, \mathrm{Pb}$, and $\mathrm{Cd}$, in water samples over 
four consecutive seasons and studies some environmental parameter for the study area.

\section{MATERIALS AND METHODS}

\section{Study Area}

Timsah Lake is a small and shallow lake, lies on the Suez Canal at mid-way between Port Said and Suez. It lies between latitude $30^{\circ} 32^{\prime}$ and $30^{\circ} 36^{\prime} \mathrm{N}$ and longitude $32^{\circ} 16^{\prime}$ and $32^{\circ} 21^{\prime} \mathrm{E}$ (Saad El-Din, 2013). The region divided into three basins: Timsah Lake, the western lagoon and Suez Canal pathway (Fig.1). The average depth values for the entire Timsah Lake ranging from 4 to $10 \mathrm{~m}$. In the western lagoon and southwestern part of the lake, the water depth is shallower and ranging from 2.5 to $4 \mathrm{~m}$. It is a land-engulfed embayment with a total area of $15 \mathrm{~km}^{2}$ (El-Sharkawy, 2012) and containing about $34 \times 106 \mathrm{~m}^{3}$ of water (ETPS, 1995). Several water resources enrich the lake with different kinds of water viz saline water from the Suez Canal, freshwater from Ismailia Sweet freshwater canal, partially treated wastewater through several agricultural, industrial, domestic sewage drains such as Al-Mahsama Drain, Al-Wadi Drain, Al-Bahtimi Drain, Al-Dabiaia Drain and Alforsan Drain (EEAA, 2010, 2011).

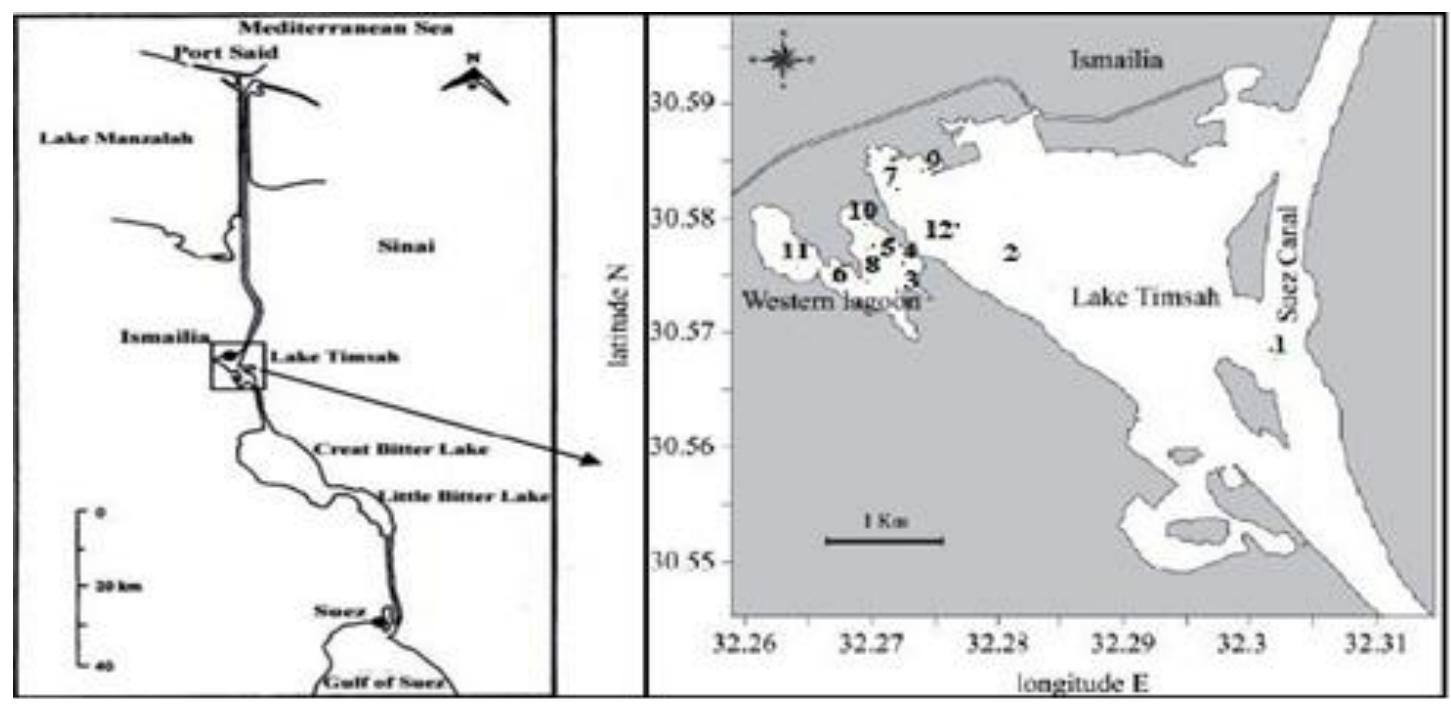

Figure (1): Map of Timsah Lake and location of sampling stations.

\section{Sampling and Environmental parameters measure- ment}

Samples of surface water were collected seasonally from 12 stations (Fig.1), representing different conditions in the western lagoon (9 stations) and Timsah Lake (3 stations) starting from spring 2014 to winter 2015. Water temperature was measured by using a simple pocket thermometer graduated to $0.1^{\circ} \mathrm{C} . \mathrm{pH}$ value was measured in situ using a portable $\mathrm{pH}$ meter model Orion 210, in addition to measuring water salinity in the field. Water transparency was estimated using white enameled Secchi disc according to (Baruah and Barthakur, 1997). Water samples were analyzed for total dissolved solids (T.D.S.) according to standard methods (APHA, 1992).

\section{Water analyses}

Samples of water were collected from a depth of 30 $\mathrm{cm}$ using Nansen bottles then stored in acid-washed polyethylene bottles for analysis. All the precautions recommended by (Kremling, 1983) to minimize risks of sample contamination were followed during the collection and treatment of samples. The blank samples were carried through all stages of the sample preparation and measurement steps. Solvent extraction was utilized using ammonium pyrrolidine dithiocarbamate (APDC) and methyl isobutyl ketone (MIBK). Water samples were pre-concentrated with APDC-MIBK extraction procedure according to the standard methods (APHA, 1989). Heavy metals in the obtained solution were measured using the Flame Atomic Absorption Spectrophotometer (Atomic absorption spectrometer AAS: Perkin Elmer A Analyst 100).

\section{RESULTS}

\section{Environmental parameters}

A spatial variability of different water quality parameters are shown in table (1). From that table, it is clear that water temperature did not deviate from the normal fluctuations of the Egyptian waters $\left(26.4-32.7^{\circ} \mathrm{C}\right) . \mathrm{pH}$ of Timsah Lake and western lagoon that lies in the alkaline side in all the studied stations, the lowest $\mathrm{pH}$ value was 7.33 recorded in station (5) (at Mahsama drain). The highest $\mathrm{pH}$ value was 9.20 in station (12) (at the bridge in the western lagoon). Variation in salinity appeared to be the key factor to all changes in the lake's water quality. Assessment of water from different stations in Timsah Lake showed salinity, a minimum of (1.50\%) exists in the western site, and a maximum of (33.7 \%o) was recorded in the eastern site in Timsah Lake.

Values of total dissolved solids (T.D.S.) that was rec- 
orded near the south western side are very high. The lake is considered a low transparent water body; transparency increased gradually eastwards and recorded a fluctuation between 0.20 and $0.95 \mathrm{~m}$.

\section{Levels of heavy metals in the water of the study area}

Table and figure (2) illustrated that the heavy metals in water follows the order: $\mathrm{Fe}>\mathrm{Zn}>\mathrm{Pb}>\mathrm{Cu}>\mathrm{Mn}>$ $\mathrm{Co}>\mathrm{Cr}>\mathrm{Cd}>\mathrm{Ni}$. Iron ( $\mathrm{Fe})$ in water showed high concentrations, but $\mathrm{Cd}$ and $\mathrm{Ni}$ estimated the lowest values. Generally, the concentrations of measured heavy metals in the water were not comparable in these stations.

\section{Spatial variations}

From table (2), the mean concentration of iron $(\mathrm{Fe})$ ranged from $7.181 \mu \mathrm{g} / \mathrm{L}$ at station (5) to $15.34 \mu \mathrm{g} / \mathrm{L}$ at station (6).

The maximum concentration of Manganese $(\mathrm{Mn})$ is
$1.044 \mu \mathrm{g} / \mathrm{L}$ and recorded at station (12) while the minimum value is $0.294 \mu \mathrm{g} / \mathrm{L}$ and recorded at station (8). Cop-per $(\mathrm{Cu})$ concentration ranged from $0.815 \mu \mathrm{g} / \mathrm{L}$ at station 11 to $1.447 \mu \mathrm{g} / \mathrm{L}$ and $1.451 \mu \mathrm{g} / \mathrm{L}$ at stations (1) and (6) respectively. The concentration of Nickel (Ni) ranged from $0.101 \mu \mathrm{g} / \mathrm{L}$ at station 10 to $0.260 \mu \mathrm{g} / \mathrm{L}$ at station (8). Zinc ( $\mathrm{Zn})$ attended its minimum value $(1.143 \mu \mathrm{g} / \mathrm{L})$ at station (8) and its highest value $(2.834 \mu \mathrm{g} / \mathrm{L})$ at station (12) Station (12) has the highest concentration of Chromium $(\mathrm{Cr})(0.441 \mu \mathrm{g} / \mathrm{L})$ while its minimum level was $0.177 \mu \mathrm{g} / \mathrm{L}$ and recorded at station (3). Cobalt (Co) has its maximum concentration ( 0.541 $\mu \mathrm{g} / \mathrm{L})$ at station (12) while its minimum one $(0.377$ $\mu \mathrm{g} / \mathrm{L})$ is at stations (5) and (8). The concentration of lead $(\mathrm{Pb})$ ranged from $0.915 \mu \mathrm{g} / \mathrm{L}$ at station (1) to $2.629 \mu \mathrm{g} / \mathrm{L}$ at station (7) in Abo Gamos drain. Finally, Cadmium $(\mathrm{Cd})$ concentration ranged from $0.235 \mu \mathrm{g} / \mathrm{L}$ at station (5) to $0.319 \mu \mathrm{g} / \mathrm{L}$ at station (12).

Table (1): Physicochemical parameters measured in the different stations in the western lagoon and Timsah Lake in the period from spring 2014 to winter 2015.

\begin{tabular}{ccccccc}
\hline \hline Station no. & Transparency $(\mathbf{c m})$ & Temperature $\left({ }^{\mathbf{0}} \mathbf{c}\right)$ & pH & Salinity (\%) & T.D.S. & Depth $(\mathbf{m})$ \\
\hline $\mathbf{1}$ & 95 & 28.1 & 8.45 & 28.87 & 15.70 & 2.50 \\
$\mathbf{2}$ & 70 & 27.0 & 8.33 & 33.69 & 19.96 & 6.00 \\
$\mathbf{3}$ & 40 & 26.4 & 7.57 & 3.00 & 12.01 & 1.00 \\
$\mathbf{4}$ & 30 & 27.4 & 8.14 & 1.50 & 510.0 & 0.50 \\
$\mathbf{5}$ & 20 & 30.5 & 7.33 & 1.55 & 620.0 & 1.00 \\
$\mathbf{6}$ & 30 & 32.7 & 7.90 & 1.66 & 670.0 & 1.00 \\
$\mathbf{7}$ & 20 & 30.0 & 8.16 & 1.95 & 980.0 & 0.50 \\
$\mathbf{8}$ & 25 & 30.9 & 8.31 & 1.65 & 645.0 & 1.50 \\
$\mathbf{9}$ & 27 & 30.3 & 8.24 & 1.57 & 610.0 & 1.00 \\
$\mathbf{1 0}$ & 20 & 31.1 & 9.00 & 1.60 & 640.0 & 0.50 \\
$\mathbf{1 1}$ & 20 & 30.8 & 9.18 & 1.61 & 665.0 & 0.55 \\
$\mathbf{1 2}$ & 25 & 31.1 & 9.20 & 1.60 & 666.0 & 0.75 \\
\hline \hline
\end{tabular}

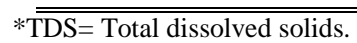

Table (2): Annual mean value of heavy metals concentration $(\mu \mathrm{g} / \mathrm{L})$ in different stations of the studied area in the period from spring 2014 to winter 2015.

\begin{tabular}{cccccccccc}
\hline \hline Station no. & $\mathrm{Fe}$ & $\mathrm{Mn}$ & $\mathrm{Cu}$ & $\mathrm{Ni}$ & $\mathrm{Zn}$ & $\mathrm{Cr}$ & $\mathrm{Co}$ & $\mathrm{Pb}$ & $\mathrm{Cd}$ \\
\hline 1 & 10.64 & 0.567 & 1.447 & 0.193 & 1.889 & 0.323 & 0.447 & 0.915 & 0.240 \\
2 & 11.78 & 0.425 & 0.986 & 0.146 & 1.486 & 0.236 & 0.387 & 1.304 & 0.267 \\
3 & 11.74 & 0.367 & 1.045 & 0.121 & 1.873 & 0.177 & 0.379 & 1.758 & 0.281 \\
4 & 9.605 & 0.367 & 0.979 & 0.150 & 1.472 & 0.255 & 0.389 & 1.273 & 0.265 \\
5 & 7.181 & 0.481 & 1.066 & 0.118 & 1.721 & 0.259 & 0.377 & 1.161 & 0.235 \\
6 & 15.34 & 0.323 & 1.451 & 0.129 & 1.655 & 0.387 & 0.408 & 1.269 & 0.268 \\
7 & 11.84 & 0.326 & 0.911 & 0.200 & 1.790 & 0.259 & 0.407 & 2.629 & 0.240 \\
8 & 9.635 & 0.294 & 0.986 & 0.260 & 1.143 & 0.283 & 0.377 & 1.027 & 0.241 \\
9 & 12.33 & 0.422 & 1.247 & 0.114 & 1.265 & 0.248 & 0.459 & 1.355 & 0.273 \\
10 & 8.688 & 0.377 & 1.091 & 0.101 & 1.475 & 0.338 & 0.456 & 1.527 & 0.277 \\
11 & 11.96 & 0.668 & 0.815 & 0.235 & 2.689 & 0.274 & 0.481 & 1.575 & 0.290 \\
12 & 12.66 & 1.044 & 0.875 & 0.191 & 2.834 & 0.441 & 0.541 & 1.101 & 0.319 \\
Mean & 11.12 & 0.472 & 1.075 & 0.163 & 1.774 & 0.290 & 0.426 & 1.408 & 0.266 \\
\hline \hline
\end{tabular}




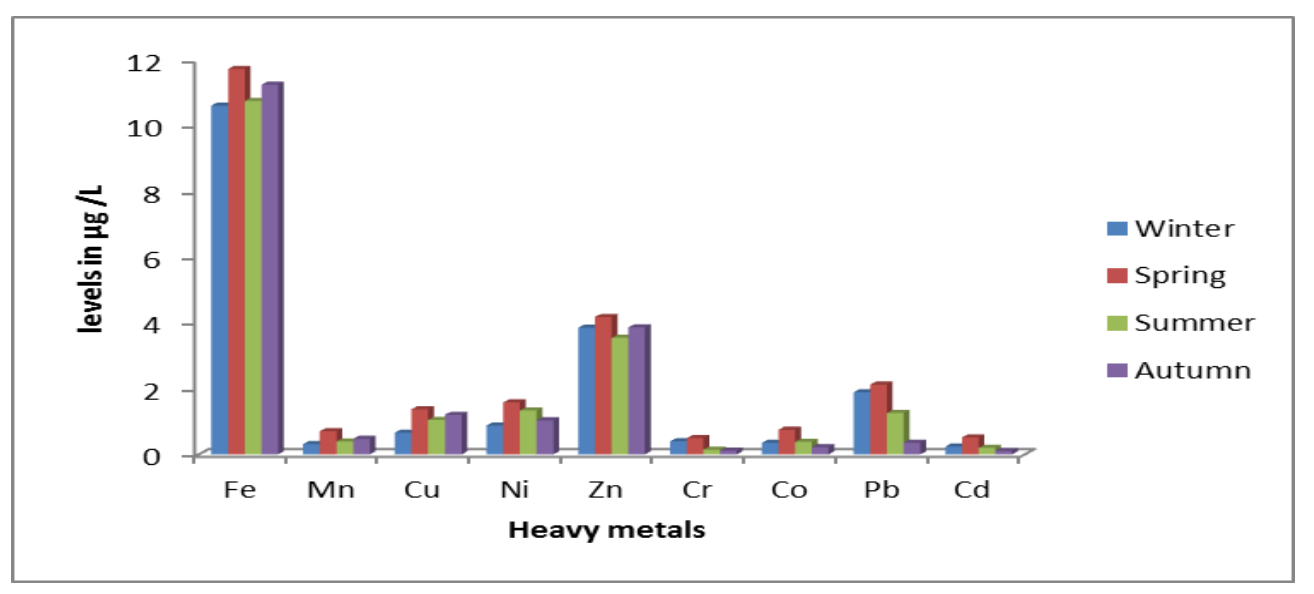

Figure (3): Seasonal variations of the mean values of heavy metals concentration in the study area in the period from spring 2014 to winter 2015.

The results revealed that heavy metals concentration is significantly higher in the northern and western edges of the lake than in the middle. Stations (5, 7, 9 and 12) at the western lagoon recorded the highest levels of almost all of the studied metals.

\section{Seasonal variations}

Figure (3) shows that in winter the highest mean value of $\mathrm{Zn}(3.856 \mu \mathrm{g} / \mathrm{L})$ and the lowest mean values of $\mathrm{Fe}, \mathrm{Mn}, \mathrm{Cu}$, and $\mathrm{Ni}$ were recorded. Spring has the highest mean concentration values for the most studied metals. The lowest mean value of $\mathrm{Zn}$ is $0.858 \mu \mathrm{g} / \mathrm{L}$ was recorded in summer. The highest mean value of $\mathrm{Ni}$ $(0.182 \mu \mathrm{g} / \mathrm{L})$ and the lowest mean values of $\mathrm{Cr}, \mathrm{Co}, \mathrm{Pb}$, and $\mathrm{Cd}$ were found in autumn.

\section{DISCUSSION}

\section{Environmental parameters}

$\mathrm{pH}$ of Timsah Lake and western lagoon lies in the alkaline side in all the studied stations, the lowest $\mathrm{pH}$ value was recorded in station (5) (affected by Mahsama drain) while the highest $\mathrm{pH}$ value in station (12) (at the bridge in the western lagoon). Variation in salinity appeared to be the key factor to all changes in the lake's water quality. The lowest salinity $(1.50 \%)$ exists in the western site due to freshwater discharged from sewage treatment systems, untreated source and nonpoint source runoff (EL-Mahsama drain and Abu Gamous drain pours in), whereas the highest salinity was recorded in the eastern site in Timsah lake where this site receives sewage water from Covered drain and small amount of freshwater from the Ismailia Canal these results nearly agreed with those reported by (Mourad, 1996) and (Eissa et al., 2008).

Values of total dissolved solids (T.D.S.) that was recorded near the south western side are very high due to the outfall of domestic and industrial wastewater. The average depth values for the entire Timsah Lake range from 4 to $10 \mathrm{~m}$ except in the western lagoon and southwestern part of the lake, where the water depth is shallower and ranges from 0.5 to $1 \mathrm{~m}$. Thus the western lag- oon and south-western part of Lake Timsah (shallow depths) represent good environments for aquatic macroinvertebrates to exist (Saad El-Din et al., 2013). The lake is considered a low transparent water body, due to the huge pollution loads (El-Sherbiny et al., 2011), transparency increased gradually eastwards.

\section{Heavy metal contents in water samples}

The variation of metal concentrations in the water collected from 12 main locations studied in Timsah Lake and western lagoon depends on the amount and the type of the effluent drained in the study area (AbdelAzim, 2002 and Abd El Samie et al., 2008). This agreed with (Hamed and Emara, 2006; Gabr and Gab-Alla, 2008), who studied the heavy metal concentration in the Red Sea and Timsah Lake and found that Fe reached the maximum value in water.

\section{Spatial variations}

From the above results, it is apparent that heavy metals concentrations are significantly higher in the northern and western edges of the lake than in the middle. Stations (5, 7, 9 and 12) at the western lagoon recorded the highest levels of almost all of the studied metals. These stations characterized by receiving a massive amount from agriculture, domestic and industrial pollutant. Except for $\mathrm{Cu}$ at station (1), recorded the lowest level of studied metals at Timsah Lake stations, which lies away from the sources of pollution and their effects. For $\mathrm{Cu}$, station (1) is located in the El-Taoon Zone, where the Arab Contractors Company is located so this might be attributed to the construction and repairing of ships and their pollutants in this area beside the antifouling paints and the activities of fishermen there (Abd El Samie et al., 2008). The main reason for high metal levels is attributed to discharge of untreated wastes from drainage (mainly sewage) and agriculture effluents at the western lagoon. Additionally, the effect of Ismalia canal, shipyard of the Suez Canal and sewage discharge from Ismailia city and other small villages restricted at these stations (Abdel Sabour et al., 1998; Abd El-Azim, 2002 and Donia, 2011). 


\section{Seasonal variations}

Seasonally, from the results, except $\mathrm{Ni}$ and $\mathrm{Zn}$, which had their highest level at autumn and winter respectively, all studied metals had their highest annual mean at spring. It appears that seasonal variation was not only affected by changes in temperature or physical parameters but strongly affected by seasonal variation of human activities and sources of pollution to the western lagoon and Timsah Lake (Abd El-Azim, 2002).

Comparing the previous studies of Timsah Lake water, (Saad El-Din and Gad El-Hak, 2017), found lower metal concentrations; (El-Shenawy, 2004) obtained lower $\mathrm{Cu}, \mathrm{Fe}$, and $\mathrm{Mn}$ levels but higher Ni levels; (Ibrahim and Abu El-Regal, 2014) recorded higher values of $\mathrm{Cr}$; and (Saad El-Din et al., 2014) found a higher value of $\mathrm{Co}$ and $\mathrm{Cr}$ respectively than in the present study.

\section{CONCLUSION}

Western lagoon located in the west of Timsah Lake and connected to it through a canal under the bridge. It's characterized by its low salinity due to the abundance of fresh water. Western lagoon considered the main source of pollution of the Timsah Lake as it dumps large amounts of sewage, agricultural and industrial pollutants that are mostly not fully treated. Most of these pollutants, especially heavy metals transferred to Timsah Lake and mixed with its water resulting in pollution of the lake.

Timsah Lake is a small semi-closed lake affected by these pollutants that have a dangerous effect on its environment. Timsah Lake is the main source of fish and other marine organisms for the province of Ismailia. Accordingly, discharging effluents from different sources to the western lagoon and consequently, Timsah Lake without adequate treatment is the major source of contamination which concentrated along the shallow boundaries of the lake which results of water stratification, slow water current, and low dilution rate, all these can affect the lake and Suez Canal environment.

Finally, it is necessary to know the sources and types of pollution and to purify and treat it before reaching the lake to keep it clean as it has a great importance in the province of Ismailia in terms of tourism and fish wealth.

\section{ACKNOWLEDGEMENTS}

The authors are grateful to National Institute of Oceanography and Fisheries (NIOF) and faculty of science, Suez Canal University for providing the research facilities.

\section{REFERENCES}

ABD EL-AZIM, H. 2002. Heavy metals in Suez Canal relevant to the impacts of land-based sources. Ph. D. Thesis, Fac. Sci., El-Mansoura Univ., Egypt.

ABD EL SAMIE, S.G., M.S. HAMZA AND H.B. HASSAN. 2008. 9th International Conference of
Nuclear Sciences and Applications. 11-14 Feb 2008 Sharm El-Shiekh Sinai Egypt.

ABDELSABOUR, M.F., R.O. ALY, M.T. KHALI AND A.H.A. ATTWA. 1998. Indicators of Lake Temsah potential pollution by some heavy metals ii) heavy metals in sediment. International Conference on hazardous waste Sources, Effects, and Management

APHA (AMERICAN PUBLIC HEALTH ASSOCIATION). 1989. Standard methods for the examination of water and wastewater, part 3, determination of metals, $17^{\text {th }}$ ed. Washington, D. C: American Water Works Association and Water Pollution Control Federation, 164p.

APHA (AMERICAN PUBLIC HEALTH ASSOCIATION). 1992. Standard Methods for the Examination of Water and Wastewater: $18^{\text {th }}$ ed. American Public Health Association, Washington, DC.

BARUAH, S., K.R. HAZARIKA, AND K.P. SARMA. 2011. Uptake and localization of Lead in Eichhornia crassipes grown within a hydroponic system Adv. in App. Sci. Res. 3(1): 51-59.

BARUAH, T.C., AND H.P. BARTHAKUR. 1997. A Textbook of Soil Analysis, Vikas Publishing House, PVT, Ltd., pp: 334.

DEMBITSKY, V.M. 2003. Oxidation, epoxidation and sulfoxidation reactions catalysed by haloperoxidases. Tetrahedron 59 (26): 4701-4720.

Donia, N. 2011. Water quality management of lake Temsah, Egypt using geographical information system (GIS). International Journal of Environmental Science and Engineering (IJESE). Vol. 2: 1-8.

EEAA (Egyptian Environmental Affairs Agency). 2010. Annual Report for the Survey Program of the Egyptian Lakes Lake El-Temsah, pp: 1-10.

EEAA (Egyptian Environmental Affairs Agency). 2011. Annual Report for the Survey Program of the Egyptian Lakes Lake El-Temsah, pp: 1-10.

EISSA, I.A.M., A.F. BADRAN AND A. MAGHAWRI. 2008. Studies on the prevailing problems associated with fish anomalies in Lake Temsah SCVMJ XIII (1) 127-139.

EL-SEREHY, H.A.H., AND M.A. SLEIGH. 1992. Physico-chemical conditions for plankton in Lake Timsah, a saline lake on the Suez Canal. Estuarine, Coastal and Shelf Science 34 (2): 127-139.

EL-SHARKAWY, A. 2012. Ph.D. Thesis, Univ. Calgary.

EL-SHENAWY, N.S. 2004. Heavy-Metal and Microbial Depuration of the Clam Ruditapes decussatus and Its Effect on Bivalve Behavior and Physiology. Environmental Toxicology, 19: 143-153.

EL-SHERBINY, M.M., A.M. AL-AIDAROOS AND A. GAB-ALLA. 2011. Seasonal composition and population density of zooplankton in Lake Timsah, Suez Canal, Egypt. OCEANOLOGIA 53 (3): 837-859.

ETPS (ENVIRONMENTAL TESTING OF POLLUTION STATUS). 1995. Water Reuse Centre for Research and Training, Ismailia, Egypt, 356.

GABR, H.R., AND A. GAB-ALLA. 2008. Effect of tra- 
nsplantation on heavy metal concentrations in commercial clams of Lake Timsah, Suez Canal, Egypt. Oceanologia 50 (1): 83-93.

HAMED, M.A., AND A.M. EMARA. 2006. Marine mollusks as bio monitors for heavy metal levels in the Gulf of Suez, Red Sea. Journal of Marine Systems 60 (3-4): 220-234.

IBRAHIM, N.K. AND M.A. ABU EL-REGAL. 2014. Heavy Metals Accumulation in Marine Edible Molluscs, Timsah Lake, Suez Canal, Egypt. ARPN Journal of Science and Technology. Vol. 4 (4): 242-244.

KAISER, M., A. AMIN AND H. ABOULELA. 2009. The International Book Geoscience and Remote Sensing. pp: 57-70.

KAMEL, A.K. 2013. Phytoremediation Potentiality of Aquatic Macrophytes in Heavy Metal Contaminated Water of El-Temsah Lake, Ismailia, Egypt. Middle East Journal of Scientific Research 14 (12): 1555 1568.

KREMLING, K. 1983. Trace metal fronts in European shelf waters. Nature 303: 225 - 227.

MEHANNA, S.F., ABD EL-AZIM, H. AND BEL-
AL, A.A. 2016. Impact of metal pollution, food avail-ability and excessive fishing on Rhabdosargus haffara stock (family: Sparidae) in Timsah Lake. Environ Sci Pollut Res. 23:15888-15898.

MOURAD, F.A. 1996. M. Sc. thesis, Suez Canal Univ., Ismailia, Egypt.

SAAD EL-DIN, M., A. GABER, M. KOCH, S.R. AHMED AND I. BAHGAT. 2013. Remote sensing application for water quality assessment lake Timsah, Suez Canal, Egypt. Journal of Remote Sensing Technology. 1(3): 61-74.

SAAD El-DIN, M.I. AND H.N. GAD EL-HAK, 2017. Impact of heavy metals concentration on spring abundance of aquatic macro-invertebrates inhabiting in Lake Timsah, Egypt. Journal of Water Security, Vol. 3:1-6.

SAAD El-DIN, M.I., Y. SAKIKO, S.Z MOHAMED, M.A. BEDIR, I.M. BAHGAT, AND O. NISHIMURA, 2014. Investigating the use of Sphaeroma serratum (Crustacea, Isopoda) as bioindicator for heavy metals pollution in Lake Timsah, Suez Canal using alkaline comet assay technique. Egypt. Acad. J. Biolog. Sci., 6(1): 7-26.

\section{تلوث المياه بالمعادن الثقيلة في المصرف الغربى وتأثيرها على بحيرة التمساح وبالتالي على قناة السويس}
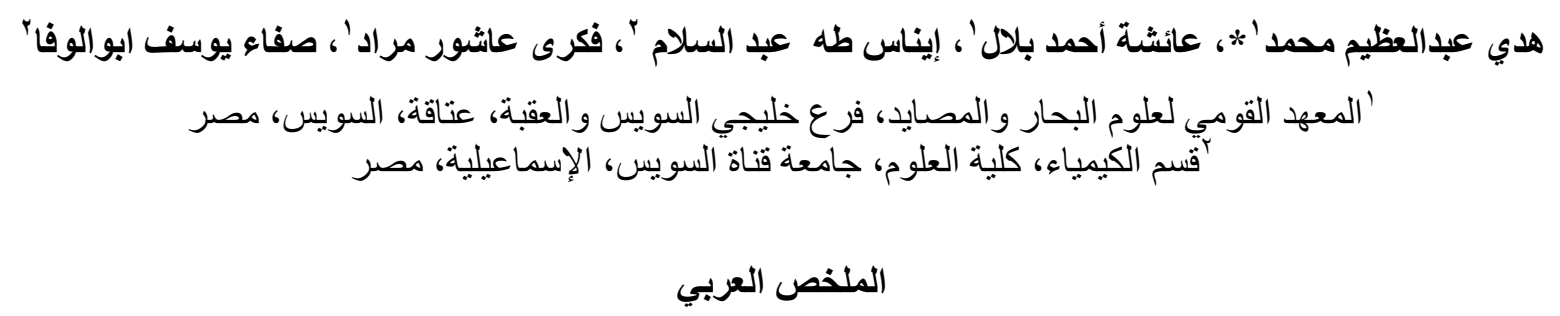

اهتمت هذه الدراسة بتقييم المصادر ومستوى التلوث وذللك بقياس تسعة معادن ثقيلة (الحديد، المنغنيز، النحاس، النيكل،

الزنلك، الكروم، الكربو هيدرات، الكادميوم) في مياه البحيرة، وما يتعقبه من تأثير على المياه المحيطة. تم جمع المعادن الثقيلة من

اثني عشر محطة بشكل موسمي بداية من ربيع ع 1 ـ إلى شتاء 10 ـ ب. تم جمع العينات من المحطات البرية و البحرية من بحيرة

التمساح بما في ذللك البحيرة الغربية وقناة السويس. من النتائج، يتضح أن المعادن الثقيلة في الماء تتبع الترتيب: حديد > زنك > رصاص > نحاس > منجنيز> كوبلت > كادميوم > نيكل. تركيز المعادن الثقيلة أعلى في الجوانب الثمالية والغربية للبحيرة من الوسط. سجلت المحطات ه و V و 9 و با في البحيرة الغربية أعلى مستويات لمعظم المعادن التي تمت در استها، وهذه المحطات تتميز بكميات عالية جداً من الملوثات الناجمة عن النفايات الزراعية والصناعية. سجل الحديد والنحاس أعلى مستوياتها في المحطة رقم 7 في منطقة مصرف المحسمة. أما أدنى مستويات الفلزات المدروسة سجلت في بحيرة التمساح والتي تقع بعيداً عن مصادر التلوث و آثاره. 